\title{
Kondisi Biometrik Kerang Darah, Tegillarca granosa, di Pesisir Pantai Utara Kota Banda Aceh
}

\section{(Biometric Conditions of Cockle Shells, Tegillarca granosa, in the Northern Coastal of Banda Aceh)}

\author{
Ilham Zulfahmi ${ }^{1 \star}$, Kamaliah Helmi ${ }^{2}$, Siti Rahmah ${ }^{3}$, Neri Kautsari ${ }^{4}$, Siti Maulida ${ }^{5}$, Firman Muhammad Nur ${ }^{6}$
}

(Diterima Juli 2021/Disetujui Agustus 2021)

\begin{abstract}
ABSTRAK
Kerang darah, Tegillarca granosa (Linnaeus, 1758), merupakan salah satu organisme akuatik bernilai ekonomis penting. Oleh karenanya, informasi terkait kondisi biometrik kerang darah penting dikaji dalam rangka optimalisasi pengelolaan sumber daya. Penelitian ini bertujuan untuk menganalisis kondisi biometrik kerang darah yang dikoleksi dari pesisir pantai utara Kota Banda Aceh. Pengambilan sampel kerang darah dilakukan di tiga lokasi, yaitu Alue Naga, Tibang, dan Deah Raya. Total sebanyak 300 kerang darah berhasil diobservasi. Parameter biometrik yang diamati meliputi distribusi kelas panjang dan bobot, hubungan antara panjang dan bobot, faktor kondisi, rasio dan korelasi antara bobot total, bobot daging, dan bobot cangkang. Hasil penelitian menunjukkan bahwa mayoritas kerang darah yang ditemukan di Deah Raya berada pada kelas ukuran panjang dan bobot yang lebih kecil (30-32 mm dan 12,25-17,24 g) dibandingkan dengan kerang dari Alue Naga (33-35 mm dan 17,25-22,24 g) dan Tibang (42-44 $\mathrm{mm}$ dan 22,25-27,24 g). Kerang darah yang diperoleh dari ketiga lokasi memiliki pola pertumbuhan (alometrik negatif) dan nilai faktor kondisi yang identik, namun demikian, kerang darah yang dikoleksi dari Alue Naga cenderung memiliki rasio bobot daging yang lebih tinggi dibanding kerang darah yang dikoleksi dari kedua lokasi lainnya. Begitupun dengan nilai korelasi antara bobot daging dan bobot total kerang darah yang dikoleksi dari Deah Raya cenderung lebih rendah dibanding yang diperoleh dari Alue Naga dan Tibang, yaitu masing-masing 0,55; 0,81; dan 0,78 .
\end{abstract}

Kata kunci: biometrik, faktor lingkungan, Deah Raya

\section{ABSTRACT}

The blood clam, Tegillarca granosa (Linnaeus, 1758) is one of the economically important aquatic organisms. Therefore, information related to biometric conditions is crucial as preventive and responsive efforts to manage blood clams. This study aims to analyze the biometric condition of blood clams collected from the northern coast of Banda Aceh City. Blood-clam samples were collected from three locations, namely Alue Naga, Tibang, and Deah Raya. A total of $\mathbf{3 0 0}$ blood clams were observed. The biometric parameters included the distribution of length and weight classes, the relationship between length and weight, condition factors, ratios, and correlations between total weight, meat weight, and shell weight were measured. The results showed that the majority of blood clams found in Deah Raya were in the smaller length and weight classes (30-32 mm and 12,25-17,24 g) compared to those found in Alue Naga (33-35 mm and 17,25-22,24 g) and Tibang (42-44 $\mathrm{mm}$ and 22,25-27,24 g). Despite having identical growth patterns (negative allometric) and condition-factor values, the blood clams collected from Alue Naga had higher meat weight ratios than those collected from the other two locations. The correlation values between the weight of the meat and the total weight of the blood clams collected from Deah Raya tends to be lower than those of blood clams obtained from Alue Naga and Tibang, which are 0,$55 ; 0,81$; and 0,78 , respectively.

Keywords: biometric, environmental factor, Deah Raya

Program Studi Pemanfaatan Sumberdaya Perikanan, Fakultas Kelautan dan Perikanan, Universitas Syiah Kuala, Kopelma Darussalam, Banda Aceh, Aceh, 23111

2 Program Studi Biologi, Fakultas Sains dan Teknologi, Universitas Islam Negeri Ar-Raniry, Kopelma Darussalam, Banda Aceh, Aceh, 23111

3 Pusat Kajian dan Konservasi Akuatik, Universitas Islam Negeri Ar-Raniry, Kopelma Darussalam, Kota Banda Aceh, Aceh, 23111

4 Program Studi Manajemen Sumberdaya Perairan, Fakultas Peternakan dan Perikanan, Universitas Samawa, Sumbawa, Nusa Tenggara Barat, 84316

5 Program Studi Budidaya Perairan, Fakultas Kelautan dan Perikanan, Universitas Syiah Kuala, Kopelma Darussalam, Banda Aceh, Aceh 23111

6 Program Doktor Matematika dan Aplikasi Sains, Program Pascasarjana, Universitas Syiah Kuala, Kopelma Darussalam, Banda Aceh, Aceh 23111

* Penulis Korespondensi:

E-mail: ilham.zulfahmi@unsyiah.ac.id

\section{PENDAHULUAN}

Pesisir pantai utara Kota Banda Aceh merupakan salah satu wilayah dengan aktivitas domestik yang cukup padat. Ragam aktivitas manusia di wilayah ini meliputi aktivitas permukiman, pariwisata, dan perikanan. Menurut Ketjulan et al. (2019), keberadaan kawasan permukiman dan pariwisata berpotensi memberikan pengaruh negatif pada ekosistem perairan di sekitarnya. Beberapa di antara dampak negatif tersebut adalah sedimentasi, eutrosifikasi, anoksia (kekurangan oksigen), dan kontaminasi polutan 
(Restrepo \& Escobar 2018; Cibic et al. 2019; Zhou et al. 2020). Kerang darah, Tegillarca granosa (Linnaeus 1758) atau yang sebelumnya dikenal dengan nama Anadara granosa, merupakan salah satu jenis organisme perairan bernilai ekonomis penting yang rentan terkena dampak negatif aktivitas di wilayah pesisir. Selain berdampak langsung pada mata pencaharian petani kerang, penurunan kelimpahan kerang darah juga ikut mengganggu ketersediaan pangan sehat bagi masyarakat sekitar. Secara ekonomis, harga kerang darah mencapai Rp. 25.000 $/ \mathrm{kg}$. Sementara itu, berdasarkan kandungan nutrien, kerang darah mengandung protein $18,91 \%$, lemak $2,66 \%$, karbohidrat $4,16 \%$, serta beberapa komponen mineral lainnya yang berpotensi sebagai antioksidan (Chi et al. 2015; Sukina et al. 2020)

Kerang darah umumnya terdistribusi pada daerah pasang surut dengan komposisi sedimen berupa lumpur dan lumpur berpasir (Joni et al. 2019). Kerang darah mampu berkembang dengan baik pada kisaran salinitas mulai dari 26 sampai 31 ppt (Yurimoto et al. 2014). Di samping itu, parameter fisika-kimiawi air dan sedimen lainnya, seperti kandungan C-organik serta polutan juga ikut memengaruhi kelangsungan hidup pertumbuhan kerang darah (Hashim et al. 2020; Mohamat-Yusuff et al. 2020; Yurimoto et al. 2021). Menurut Yurimoto et al. (2008), kandungan bahan organik merupakan salah satu sumber nutrien utama bagi hewan bentos (termasuk kerang darah). Fluktuasi parameter lainnya, seperti suhu perairan, dilaporkan telah memicu terjadinya gametogenesis, diferensiasi sel induk menjadi gamet jantan atau betina, serta memengaruhi penyerapan nutrien pada bivalvia (Bayne et al. 1979). Di sisi lain, paparan polutan, di antaranya nitrit, pada kerang darah ikut dilaporkan menimbulkan dampak negatif berupa gangguan fungsi enzim dan metabolisme (Hashim et al. 2020)

Kondisi biometrik merupakan parameter penting dalam biologi perikanan yang dapat digunakan untuk menilai kesehatan, produktivitas, dan kondisi fisiologi organisme akuatik (Zulfahmi et al. 2021a; Zulfahmi et al. 2021b). Beberapa parameter kondisi biometrik yang umum diamati meliputi sebaran kelas panjang, sebaran kelas bobot, serta hubungan antara panjang bobot dan faktor kondisi. Menurut Ali et al. (2001), kondisi biometrik organisme akuatik dapat dipengaruhi oleh beberapa faktor, seperti perbedaan jenis kelamin, ketersediaan makanan, serta kondisi lingkungan perairan. Sejauh ini, penelitian terkait kondisi biometrik berupa sebaran kelas dan hubungan antara panjang bobot dan faktor kondisi kerang darah telah dilakukan di beberapa kawasan di Indonesia yang meliputi Perairan Muara Gembong, Bekasi (Dody et al. 2018), Perairan Pesisir Kota Semarang (Prasojo et al. 2012; Suryono \& Suprijanto 2014), dan Perairan pesisir Bagan Siapi-api, Kabupaten Rokan Hilir (Dewi et al. 2019). Walaupun demikian, sampai saat ini informasi mengenai kondisi biometrik kerang darah dari perairan pesisir Aceh masih belum diungkap. Oleh karena itu, penelitian ini bertujuan menganalisis kondisi biometrik kerang darah (Tegillarca granosa) yang dikoleksi dari pesisir pantai utara Kota Banda Aceh.

\section{METODE PENELITIAN}

Pengambilan data dilakukan selama tiga bulan, mulai dari bulan April sampai Juni 2019. Penentuan stasiun penelitian dilakukan secara purposive sampling berdasarkan perbedaan karakteristik ekologi. Stasiun 1 (N 05 35'53.10", E 095²1'01.38”) berlokasi di kawasan Alue Naga dengan karakteristik lokasi berdekatan dengan muara sungai. Stasiun 2 (N 05³5'35.71", E 095 $20^{\circ}$ '57.16”) berlokasi di kawasan Tibang dengan karakteristik lokasi berada di sekitar areal manggrove. Stasiun 3 (N 05³5'31.69" E 095'19'34.28") berlokasi di Deah Raya dengan karakteristik lokasi berdekatan dengan kawasan permukiman dan tempat wisata (Gambar 1).

\section{Prosedur Kerja}

Sampel kerang dari setiap stasiun dikoleksi secara tradisional dengan menggunakan alat bantu penggalian tanah sederhana. Sampel yang berhasil dikoleksi kemudian dimasukkan ke dalam wadah plastik yang telah diberi label. Bersamaan dengan pengambilan sampel kerang, ikut dilakukan pengukuran parameter kualitas air dan sedimen, baik secara in situ dan ex situ meliputi salinitas, suhu, oksigen terlarut, $\mathrm{pH}$ air, kandungan C-organik dalam sedimen, serta karakteristik sedimen. Sampel sedimen masingmasing sebanyak $500 \mathrm{~g}$ dikoleksi dari tiap lokasi dengan metode coring vertikal menggunakan pipa paralon berukuran 2,5 inci hingga kedalaman $20 \mathrm{~cm}$. Sedimen kemudian dimasukkan ke dalam wadah plastik yang telah diberi label dan dibawa ke laboratorium untuk dianalisis lebuh lanjut.

Di laboratorium, sampel kerang darah yang telah dibersihkan diukur panjang cangkangnya dengan menggunakan kaliper digital dengan ketelitian 0,1 $\mathrm{mm}$. Bobot total, bobot bersih, dan bobot cangkang kerang darah diukur dengan menggunakan timbangan analitik

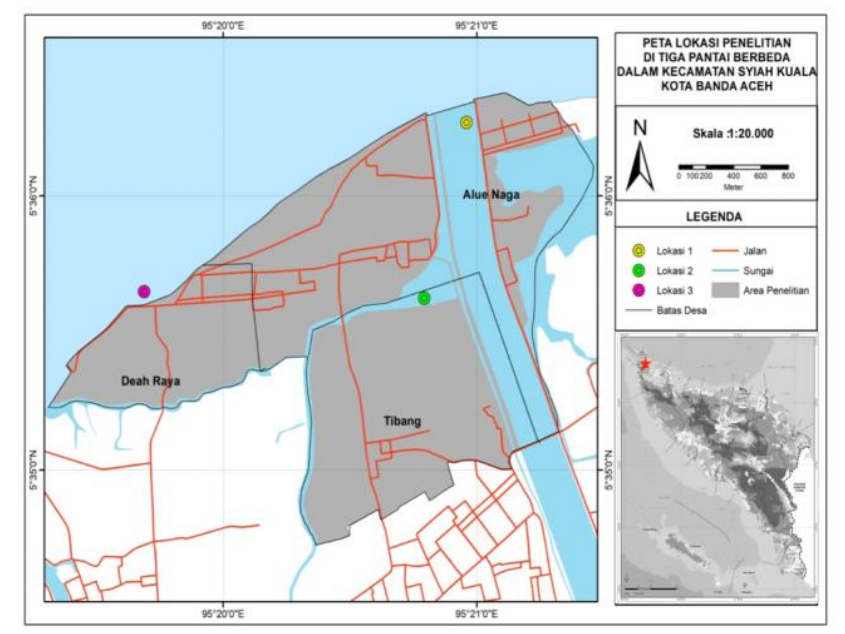

Gambar 1 Lokasi penelitian 
dengan ketelitian $0,01 \mathrm{~g}$. Sampel sedimen yang telah dikoleksi, dihomogenkan dan diayak menggunakan ayakan sedimen bertingkat $(2 ; 1 ; 0,5 ; 0,25 ; 0,125$; dan $0,063 \mathrm{~mm}$ ). Penentuan fraksi sedimen dilakukan berdasarkan ukuran butir mengacu pada skala Wenworth (Setiawan et al. 2019). Pengukuran kondisi biometrik kerang darah dan analisis fraksi sedimen dilakukan di Laboratorium Biologi, Fakultas Sains dan Teknologi, UIN Ar-Raniry, sedangkan pengukuran kandungan $C$ organik dilakukan di Laboratorium Biologi, Fakultas MIPA, Universitas Syiah Kuala.

\section{Parameter Pengamatan}

Parameter yang diamati dalam penelitian ini meliputi sebaran kelas panjang dan bobot, hubungan antara panjang dan bobot, faktor kondisi, rasio, dan korelasi antara bobot total, bobot daging, dan bobot cangkang. Penentuan jumlah kelompok ukuran kerang ditentukan dengan rumus Sturges (1926) sebagai berikut berikut:

$$
n=1+3,32 \log N
$$

Keterangan: $\mathrm{n}$ adalah jumlah kelompok ukuran, $\mathrm{N}$ adalah jumlah data pengamatan. Penentuan lebar kelas setiap kelompok ukuran kerang dihitung dengan menggunakan rumus Sturges (1926) sebagai berikut:

$$
\mathrm{c}=\frac{\mathrm{a}-\mathrm{b}}{\mathrm{n}}
$$

Keterangan: $c$ adalah lebar kelas, a adalah panjang maksimum kerang, $b$ adalah panjang minimum kerang, $\mathrm{n}$ adalah jumlah kelompok ukuran. Hubungan antara panjang cangkang dan bobot total kerang dianalisis melalui hubungan persamaan kuadrat (power regression) sebagaimana yang dilaporkan oleh De Robertis dan Williams (2008) sebagai berikut:

$$
\mathrm{W}=\mathrm{aL}^{\mathrm{b}}
$$

Keterangan: $\mathrm{W}$ adalah bobot basah kerang (g), L adalah panjang cangkang $(\mathrm{mm})$, sementara $a$ dan $b$ adalah konstanta dalam persamaan tersebut. Faktor kondisi kerang darah dihitung sesuai dengan formula yang dikemukakan oleh King (1995) sebagai berikut:

$$
\mathrm{CF}=\frac{\text { Wcal }}{\text { Wpred }}
$$

Keterangan: CF adalah faktor kondisi, $\mathrm{W}_{\text {cal }}$ adalah bobot total kerang darah secara faktual ( $g$ ) dan $\mathrm{W}_{\text {pred }}$ adalah bobot total kerang darah yang diperoleh dari persamaan hubungan panjang bobot $(\mathrm{g})$. Rasio bobot daging dan bobot cangkang kerang darah dihitung melalui persentase antara bobot daging dibanding bobot total dan bobot cangkang dibanding bobot total kerang darah.

\section{Analisis Data}

Data disajikan dalam bentuk kisaran, nilai rata-rata, dan standar deviasi. Komparasi rasio bobot bersih dan bobot cangkang kerang darah antarlokasi penelitian dianalisis menggunakan ANOVA satu arah dengan kriteria berbeda nyata pada tingkat kepercayaan 95\% $(p<0,05)$. Distribusi ukuran, hubungan panjang dan bobot, faktor kondisi dan parameter kualitas air dan sedimen antarlokasi penelitian dianalisis secara deskriptif. Korelasi antara bobot daging, bobot cangkang, dan bobot total kerang darah dari setiap lokasi penelitian dideskripsikan menggunakan regresi linear sederhana. Analisis statistik dilakukan dengan bantuan perangkat lunak SPSS 22 dan Prisma 9.

\section{HASIL DAN PEMBAHASAN}

\section{Kondisi Habitat}

Kondisi habitat merupakan satu faktor penting yang memengaruhi kelangsungan hidup dan pertumbuhan kerang darah. Tabel 1 merangkum kondisi parameter kualitas air dari tiap stasiun penelitian. Suhu perairan di ketiga lokasi penelitian berkisar antara $29.63 \pm 0.30$ hingga $31.60 \pm 0.66^{\circ} \mathrm{C}$. Suhu tertinggi teramati di Alue Naga, sedangkan suhu terendah ditemukan di kawasan Deah Raya. Kisaran suhu di ketiga lokasi penelitian tidak jauh berbeda dari lokasi lain ditemukannya kerang darah, seperti Muara Kongkong Laut (Joni et al. 2019), pesisir pantai barat Malaysia (Lai et al. 2020), dan Muara Sungai Dadapan, Sidoarjo (Triatmaja et al. 2019). Menurut Nur et al. (2020) dan You et al. (2001) suhu berperan penting menunjang kelangsungan hidup dan pertumbuhan hewan akuatik, termasuk kerang darah. Kerang darah memiliki toleransi yang tinggi terhadap fluktuasi suhu perairan, dan suhu ideal bagi habitat kerang darah berkisar dari 25 sampai $28^{\circ} \mathrm{C}$ (Shin \& Moon 2005). Perubahan suhu yang terlalu tinggi dapat menyebabkan gangguan kinerja fisiologis hingga kematian pada bivalvia. Juvenil kerang darah yang terpapar suhu di atas $37^{\circ} \mathrm{C}$ dilaporkan berpotensi meningkatkan mortalitas hingga $100 \%$ (Shin \& Moon 2005).

Terdapat perbedaan yang mencolok pada nilai salinitas antarstasiun penelitian. Deah Raya cenderung

Tabel 1 Kondisi parameter kualitas air dari setiap stasiun penelitian

\begin{tabular}{lcrrr}
\hline \multirow{2}{*}{ Parameter } & \multirow{2}{*}{ Satuan } & \multicolumn{3}{c}{ Lokasi pengamatan } \\
\cline { 3 - 5 } & & Deah Raya & Alue Naga & Tibang \\
\hline Suhu & ${ }^{\circ} \mathrm{C}$ & $29,63 \pm 0,30$ & $30,43 \pm 0,72$ & $31,60 \pm 0,66$ \\
Salinitas & $\mathrm{ppt}$ & $22,27 \pm 0,41$ & $18,33 \pm 0,08$ & $13,77 \pm 0,66$ \\
Oksigen Terlarut & $\mathrm{mg} / \mathrm{L}$ & $5,78 \pm 0,20$ & $5,78 \pm 0,20$ & $7,80 \pm 3,20$ \\
pH Air & - & $8,10 \pm 0,01$ & $8,05 \pm 0,02$ & $7,92 \pm 0,04$ \\
C-organik & $\%$ & $1,29 \pm 0,19$ & $0,60 \pm 0,08$ & $0,62 \pm 0,48$ \\
\hline
\end{tabular}


memiliki salinitas yang lebih tinggi $(22,27 \pm 0.41 \mathrm{ppt})$ dibandingkan dengan Tibang dan Alue Naga (masingmasing 13,77 $\pm 0,66$ dan 18,33 $\pm 0,08$ ppt). Salinitas yang rendah di Tibang dan Alue Naga diduga karena lokasinya yang berdekatan dengan muara sungai sehingga banyak menerima pasokan air tawar, terutama pada saat surut. Lai et al. (2020) mengungkapkan bahwa kerang darah mampu hidup dalam kisaran salinitas yang luas. Namun demikian, fluktuasi salinitas yang terlalu tinggi atau rendah dari kondisi ideal dapat mempengaruhi kinerja osmoregulasi pada kerang darah (Khade \& Mane 2012; Triatmaja et al. 2019). Kisaran oksigen terlarut berkisar antara 5,78 \pm 0,20 hingga $7,80 \pm 3,20 \mathrm{mg} / \mathrm{L}$. Nilai ini identik dengan beberapa lokasi lain ditemukannya kerang darah, seperti pesisir pantai barat Malaysia $(5,4-6,3 \mathrm{mg} / \mathrm{L})$ (Lai et al. 2020), Muara Kongkong Laut, Malaysia (4,63 $\pm 1,97-6,64 \pm 0,80 \mathrm{mg} / \mathrm{L}$ ) (Joni et al. 2019), dan Muara Sungai Dadapan, Sidoarjo ( $5 \mathrm{mg} / \mathrm{L})$ (Triatmaja et al. 2019). Nilai pH air berkisar antara 7,92 $\pm 0,04$ hingga $8,10 \pm 0,01$. Kawasan Deah Raya memiliki kandugan C-organik yang lebih tinggi dibandingkan kawasan Alue Naga dan Tibang (masing masing sebesar 1,29 \pm $0,19 \% ; 0,60 \pm 0,08 \%$; dan $0,62 \pm 0,48 \%$ ). Lokasi stasiun Deah Raya yang dekat kawasan per-mukiman dan pariwisata diduga menjadi salah satu faktor yang menyebabkan kandungan C-organik yang tinggi.

Sama halnya dengan parameter fisika kimia perairan, komposisi sedimen ikut memengaruhi kelangsungan hidup dan pertumbuhan hewan bentik, terutama yang bersifat infauna. Van der Wal et al. (2008) menyebutkan bahwa distribusi hewan bentik, terutama yang bersifat deposit feeder mempunyai hubungan yang erat dengan komposisi sedimen. Komposisi sedimen di lokasi penelitian tersusun atas lumpur, pasir sangat halus, pasir halus, pasir sedang, pasir kasar, pasir sangat kasar, dan kerikil. Akan tetapi, ketiga lokasi memiliki persentase komposisi penyusun sedimen yang berbeda-beda. Komposisi sedimen di Deah Raya dan Tibang didominasi oleh pasir sedang (61.06\% dan $31.45 \%)$. Sebaliknya, di Alue Naga didominasi oleh pasir sangat halus (27.36\%). Stasiun
Tibang memiliki persentase jumlah kerikil yang lebih banyak $(22,34 \%)$ dibandingkan di Deah Raya dan Tibang $(1,22 \%$ dan $3,08 \%)$. Sebaliknya, Alue Naga memiliki persentase lumpur yang lebih tinggi $(9,93 \%)$ dibandingkan kedua lokasi lainnya (Gambar 2). Setiawan et al. (2019) mengungkapkan bahwa komposisi sedimen di kawasan pesisir sangat dipengaruhi oleh arus pasang surut. Pesisir yang dekat dengan perairan berarus cepat, komposisi sedimennya cenderung didominasi oleh kerikil, sedangkan perairan berarus lambat cenderung didominasi oleh pasir halus dan lumpur. Menurut Dewi et al. (2019), kerang darah cenderung menyukai kawasan pesisir dengan dominasi substrat berpartikel halus. Beberapa penelitian sebelumnya mengungkapkan bahwa pada kondisi normal, komposisi sedimen berpartikel halus yang tinggi identik dengan peningkatan kandungan Corganik (Barus et al. 2019; Imamsyah et al. 2020). Namun demikian, hasil penelitian ini menunjukkan bahwa stasiun Deah Raya yang memiliki komposisi lumpur dan pasir sangat halus yang lebih rendah dibanding dua stasiun lainnya, justru memiliki kandungan C-organik yang lebih tinggi. Hal ini memperkuat dugaan adanya pengaruh aktivitas manusia yang berdampak pada peningkatan kandungan Corganik di kawasan ini. Kätterer et al. (2012) mengungkapkan bahwa limbah organik yang berasal dari aktivitas manusia dan peternakan berpengaruh signifikan meningkatkan kandungan C-organik dalam tanah/sedimen di suatu kawasan.

\section{Sebaran Kelas Panjang dan Bobot}

Mayoritas kerang darah yang dikoleksi dari Deah Raya berada pada kelas ukuran panjang dan bobot yang lebih kecil (30-32 mm dan 12,25-17,24 g) dibandingkan dengan kerang darah yang dikoleksi dari Alue Naga (33-35 mm dan 17,25-22,24 g) dan Tibang (42-44 mm dan 22,25-27,24 g) (Gambar 3). Hasil analisis statistik ikut menunjukkan bahwa kerang darah yang dikoleksi dari Deah Raya dan Alue Naga memiliki ukuran panjang cangkang dan bobot total yang lebih rendah dibandingkan dengan kerang darah asal Alue

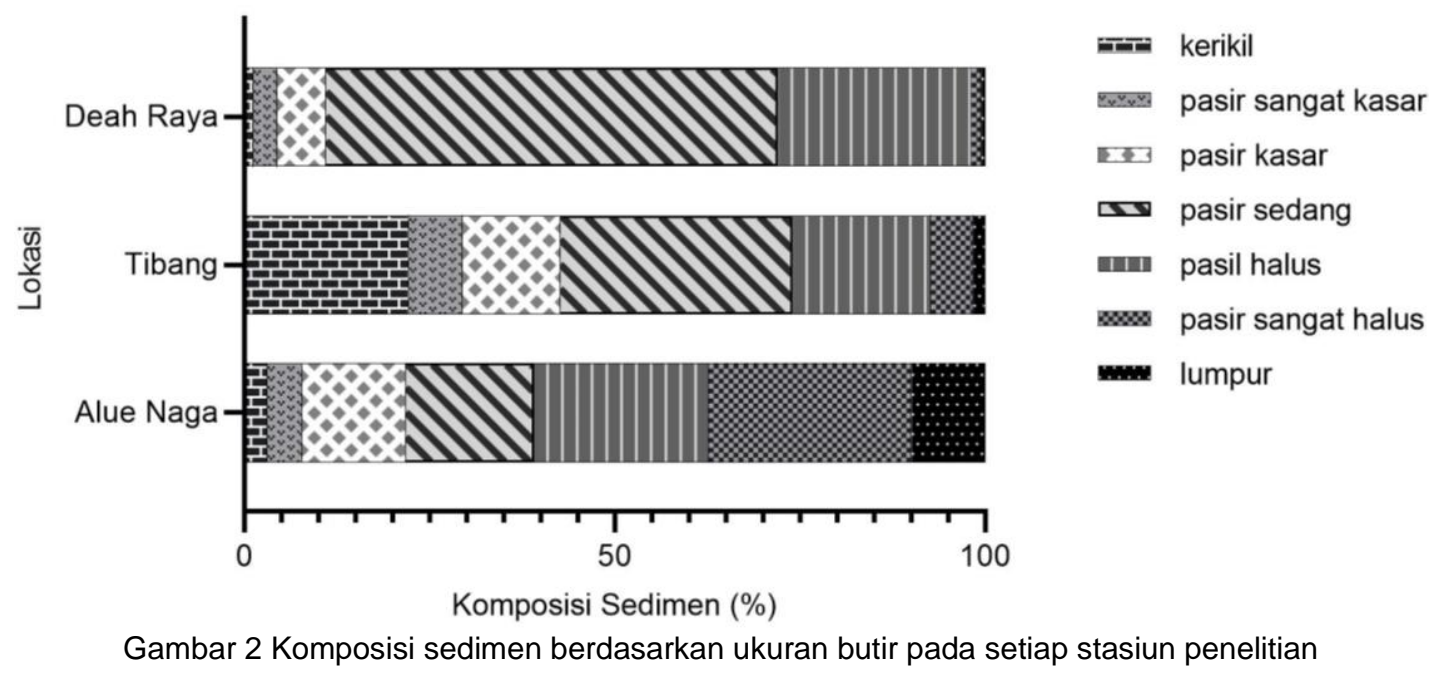


Naga (Tabel 2). Dibandingkan dengan kawasan Indonesia lainnya, kerang darah yang dikoleksi dari kawasan pesisir utara Banda Aceh memiliki ukuran panjang dan bobot yang lebih besar dibandingkan dengan kerang darah yang dikoleksi dari kawasan muara Demak $(40,9 \mathrm{~mm})$, perairan pesisir Kecamatan Genuk, Semarang $(30 \mathrm{~mm})$ dan Pesisir Kecamatan Genuk (0.5 hingga 8.6 gram) (Taufiq \& Hartati 2000; Prasojo et al. 2012). Akan tetapi, ukuran ini masih lebih kecil dibanding ukuran kerang darah dari Teluk Sungai Pisang, Sumatera Barat yang berkisar $15-67 \mathrm{~mm}$ (Nurdin et al. 2010).

Menurut Lai et al. (2020), adanya variasi ukuran panjang dan bobot kerang darah antarkawasan dapat dipengaruhi oleh faktor genetik, siklus reproduksi, ke- tersediaan makanan, dan kompetisi serta kondisi lingkungan. Sejauh ini, kajian lebih dalam terkait variasi genetik, pengaruh ketersediaan makanan, dan kompetisi dalam ekosistem yang dihuni oleh kerang darah, khususnya dari lokasi penelitian masih belum ditemukan. Yurimoto et al. (2014) melaporkan bahwa keanekaragaman bentik yang tinggi di suatu ekosistem yang diikuti dengan kompetisi untuk mendapatkan makanan dari jenis yang sama akan menyebabkan terjadinya tumpang tindih relung (overlapping ecological niches) yang berpotensi menghambat pertumbuhan. Hasil penelitian Masitah dan Chong (2002) mengungkapkan bahwa kerang darah berkompetisi dengan beberapa jenis crustacea (Mierspenaeopsis hardwickii, Mierspenaeopsis sculptilis, dan
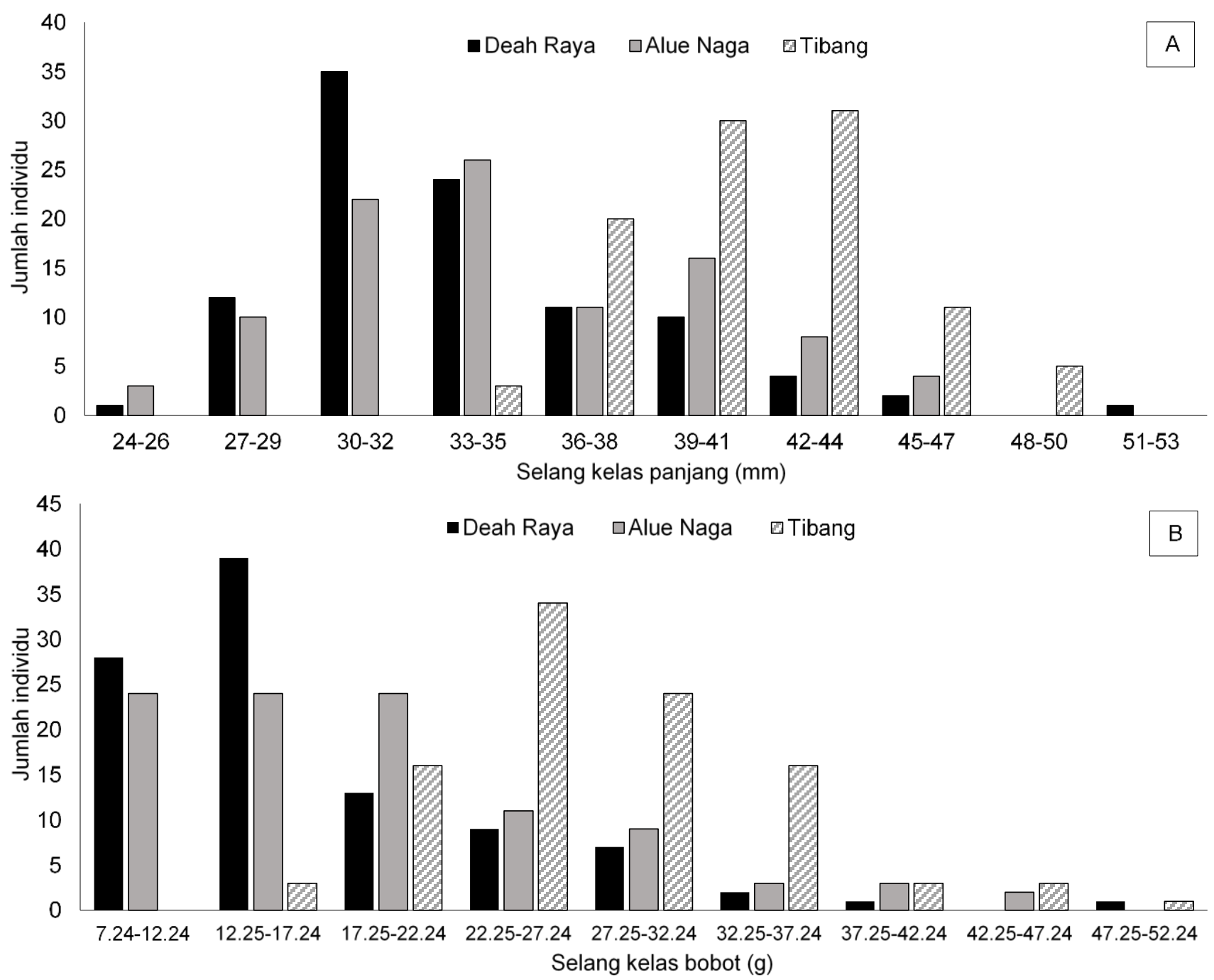

Gambar 3 Sebaran kelas panjang (A) dan bobot (B) kerang darah setiap stasiun penelitian

Tabel 2 Nilai kisaran, rerata, koefisien a dan b, serta faktor kondisi kerang darah dari setiap stasiun penelitian

\begin{tabular}{lcccrcccc}
\hline \multirow{2}{*}{ Lokasi } & \multirow{2}{*}{$\mathrm{n}$} & \multicolumn{2}{c}{ Panjang cangkang $(\mathrm{mm})$} & \multicolumn{2}{c}{ Bobot total $(\mathrm{g})$} & \multirow{2}{*}{ a } & \multirow{2}{*}{$\mathrm{b}$} & \multirow{2}{*}{ FK } \\
\cline { 3 - 6 } & & Kisaran & Rerata \pm STD & \multicolumn{1}{c}{ Kisaran } & Rerata \pm STD & & & \\
\hline Deah Raya & 100 & $26-52$ & $33,84 \pm 4,84^{\mathrm{a}}$ & $7,24-49,45$ & $17,07 \pm 7,48^{\mathrm{a}}$ & 0,0013 & 2,68 & 1,01 \\
Alue Naga & 100 & $24-47$ & $34,93 \pm 5,16^{\mathrm{a}}$ & $7,79-43,73$ & $19,13 \pm 8,44^{\mathrm{a}}$ & 0,0010 & 2,75 & 0,97 \\
Tibang & 100 & $34-50$ & $41,22 \pm 3,53^{\mathrm{b}}$ & $15,97-48,43$ & $27,60 \pm 6,53^{\mathrm{b}}$ & 0,0022 & 2,53 & 0,99 \\
\hline
\end{tabular}

${ }^{*}$ Superskrip yang berbeda dalam kolom yang sama menunjukkan perbedaan yang nyata $(P<0,05)$ 
Parapenaeopsis stylifera) untuk mendapatkan jenis makanan yang sama berupa mikroalga dan detritus.

Kondisi lingkungan merupakan salah satu faktor yang ikut berperan penting dalam memengaruhi pertumbuhan kerang darah. Jabang et al. (2006) melaporkan bahwa penyebaran kerang berukuran besar umumnya banyak ditemukan pada substrat sedimen berukuran halus, sedangkan yang berukuran lebih kecil umumya ditemukan pada daerah dengan substrat sedimen berukuran besar, seperti tepi pantai atau lokasi hempasan ombak. Di samping itu, penelitian sebelumnya oleh Joni et al. (2019) melaporkan bahwa terdapat korelasi yang positif antara tingkat salinitas dan pertumbuhan kerang darah. Pada keadaan salinitas sangat rendah, kerang darah cenderung menutup cangkangnya dalam rangka beradaptasi mempertahankan tekanan osmotik di antara jaringan dan lingkungan, dan hal ini berdampak pada pemberhentian aktivitas makan yang akhirnya akan berpengaruh pada pertumbuhan (Pathansali \& Soong 1958; Davenport \& Wong 1986). Nakamura dan Shinotsuka (2007) ikut melaporkan bahwa kenaikan suhu hingga $31^{\circ} \mathrm{C}$ dapat meningkatkan nafsu makan kerang. Sebaliknya, penurunan suhu dapat menurunkan aktivitas makan, dan menyebabkan kerang darah menggali lebih dalam. Nafsu makan yang menurun dan adanya aktivitas menggali menyebabkan penurunan energi kerang darah yang akhirnya berdampak pada gangguan pertumbuhan. Adanya gangguan pertumbuhan pada kerang darah juga dapat disebabkan oleh paparan polutan. Beberapa penelitian mengungkapkan bahwa paparan polutan, terutama dari jenis logam berat telah menyebabkan berbagai gangguan fisiologis yang dapat berdampak pada pertumbuhan kerang darah (Guan et al. 2018; Shi et al. 2019). Perlu penelitian lanjutan untuk mengkaji ada tidaknya korelasi antara kontaminasi polutan dan pertumbuhan kerang darah, terutama di kawasan Deah Raya. Selain itu, Gimin et al. (2004) menyatakan bahwa faktor reproduksi juga dapat memengaruhi pertumbuhan dan biomassa bivalvia. Selama proses reproduksi, nutrien yang diperoleh akan digunakan untuk perkembangan gonadik sehingga membuat pertumbuhan somatik melambat.

\section{Hubungan Panjang Bobot dan Faktor Kondisi}

Hubungan antara panjang-bobot dan faktor kondisi adalah dua parameter biologis yang dapat digunakan untuk merepresentasikan tingkat pertumbuhan dan kondisi organisme akuatik serta hubungannya dengan kondisi lingkungan (Zulfahmi et al. 2021b). Faktor kondisi telah umum dipakai untuk mengevaluasi kesehatan, produktivitas, dan keadaan fisiologis organisme akuatik, khususnya ikan (Zulfahmi et al. 2021a). Nilainya dapat mencerminkan keadaan fisiologisnya yang meliputi bentuk tubuh, kandungan lemak, dan tingkat pertumbuhan (Froese 2006; Stevenson \& Woods Jr 2006). Hasil penelitian menunjukkan bahwa nilai b di ketiga lokasi penelitian berkisar antara 2.53 hingga 2.75 . Nilai b tertinggi di- peroleh di Alue Naga, sedangkan nilai terendah teramati berada di Tibang. Berdasarkan nilai faktor kondisi, Deah Raya memiliki nilai yang lebih tinggi dibandingkan dengan Alue Naga $(0,97)$ dan Tibang $(0,99)$, yaitu masing-masing sebesar 1,$01 ; 0,97$; dan 0,99 (Tabel 2).

Berdasarkan nilai b diketahui bahwa kerang darah dari ketiga stasiun penelitian memiliki pertumbuhan allometrik negatif. Hal ini identik dengan beberapa hasil penelitian dari beberapa lokasi lainnya, seperti Perairan Bagan Siapi-Api (Dewi et al. 2019), Teluk Lada, Selat Sunda (Komala et al. 2011), dan Pesisir Selat Malaka (Khalil et al. 2021). Variasi dalam nilai koefisien b dan faktor kondisi kerang darah antarlokasi dapat dipengaruhi oleh berbagai faktor, seperti kondisi lingkungan, adaptasi, dan pola makan (Khalil et al. 2021).

\section{Rasio dan Korelasi Antara Bobot Total, Bobot Daging, dan Bobot Cangkang}

Analisis rasio dan korelasi antara bobot total, bobot daging, dan bobot cangkang dapat dijadikan indikator untuk menilai kinerja pertumbuhan somatik kerang darah. Hasil penelitian menunjukkan bahwa meskipun kerang darah dari ketiga lokasi memiliki nilai faktor kondisi yang hampir identik, namun kerang darah yang dikoleksi dari Alue Naga cenderung memiliki rasio bobot daging yang lebih tinggi dibanding kedua lokasi lainnya. Mengacu pada Gambar 4, kerang darah dari kawasan Alue Naga memiliki nilai rasio bobot daging yang lebih tinggi dan berbeda secara signifikan dibandingkan dengan kawasan Deah Raya dan Tibang, yaitu masing-masing sebesar 17,60\%, 14,90\%, dan $15,30 \%$. Sebaliknya, kerang darah yang dikoleksi dari Deah Raya dan Tibang memiliki rasio bobot cangkang yang lebih tinggi dan berbeda secara signifikan dibandingkan dengan kerang darah yang dikoleksi dari kawasan Alue Naga, yaitu masing-masing sebesar $85,08 \%$, 85\%, dan 82,41\% (Gambar 4). Lebih lanjut, berdasarkan nilai korelasi antara bobot daging dan bobot total, kerang darah dari Deah Raya cenderung memiliki nilai korelasi $\left(R^{2}\right)$ yang lebih rendah dibanding kerang darah dari Alue Naga dan Tibang, yaitu masingmasing 0,$55 ; 0,81$; dan 0,78 . Hasil serupa juga teramati pada nilai korelasi antara bobot daging dan bobot cangkang (Gambar 5).

Sejauh ini, kajian terkait hubungan antara rasio bobot daging dan cangkang kerang darah serta korelasinya dengan kondisi lingkungan masih jarang diungkap. Hasil penelitian Ray et al. (2018) mengungkapkan bahwa bivalvia yang hidup pada ekosistem dengan tingkat predasi tinggi cenderung mengalokasikan energinya untuk pertumbuhan dan pembentukan cangkang sebagai upaya pertahanan diri terhadap serangan predator. Sebaliknya, rasio bobot daging yang tinggi dapat mengindikasikan adanya dominansi dan kurangnya aktivitas predasi terhadap bivalvia tersebut. Di samping itu, dominannya substrat lumpur dan pasir halus di Stasiun Alue Naga dan Tibang diduga berpengaruh pada kemampuan kerang darah 
dalam mencari makan. Substrat lumpur dan pasir halus cenderung lebih mudah untuk dilalui serta berpotensi mengandung lebih banyak makanan dibandingkan dengan substrat berukuran kasar. Bivalvia umumnya diketahui sebagai penyaring deposit dengan komposisi pakan mencakup campuran detritus, mikroalga bentik, fitoplankton, dan partikel tanaman terestrial (Broom 1982; Lam \& Hai 1998; Yurimoto et al. 2014). Adapun kajian terkait pengaruh efek polutan pada proses

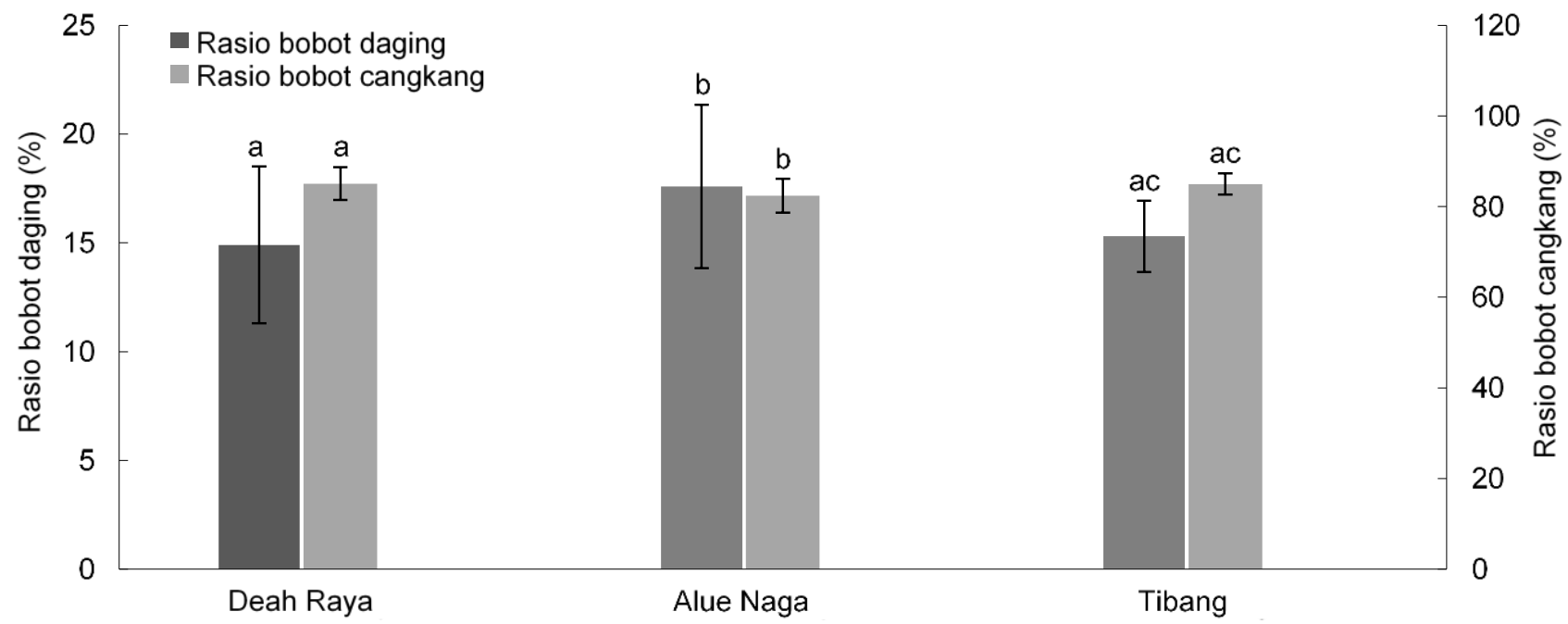

Gambar 4 Rasio bobot daging dan bobot cangkang terhadap bobot total kerang darah antarstasiun penelitian. *superskrip yang berbeda antarhistogram menunjukkan perbedaan yang nyata $(p<0,05)$.

Alue Naga

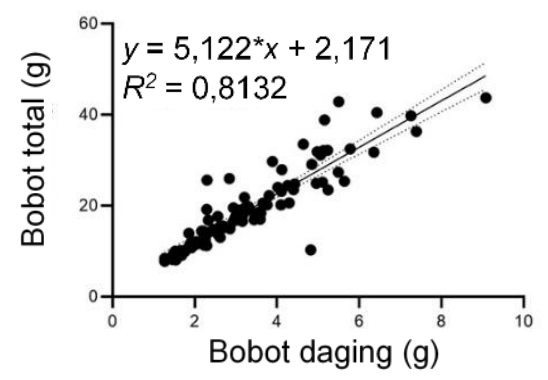

Tibang

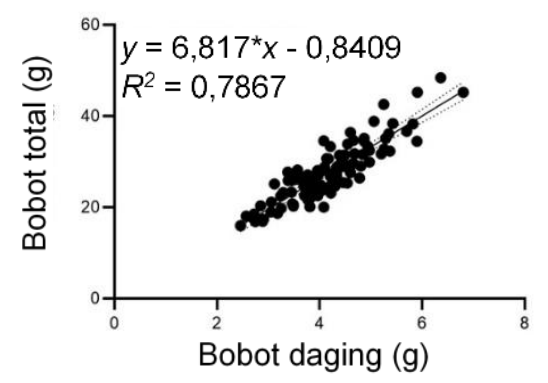

Deah Raya

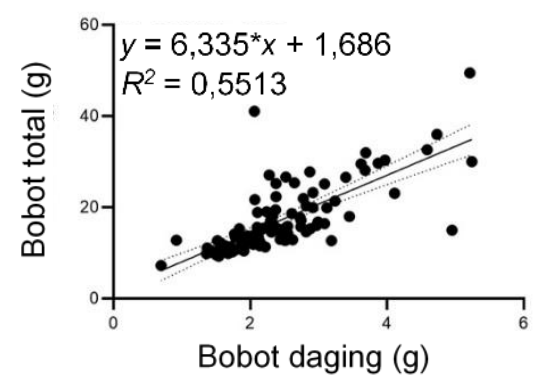

Alue Naga

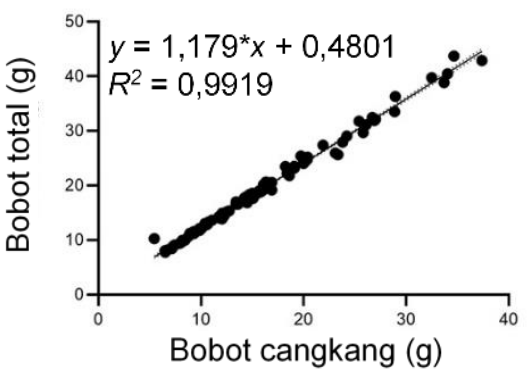

Tibang

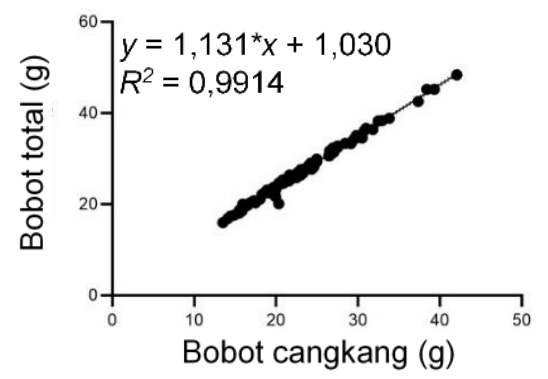

Deah Raya

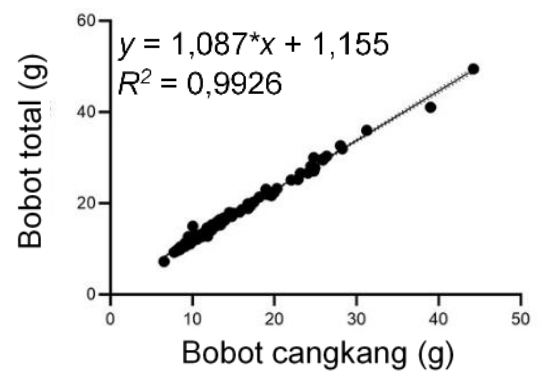

Alue Naga

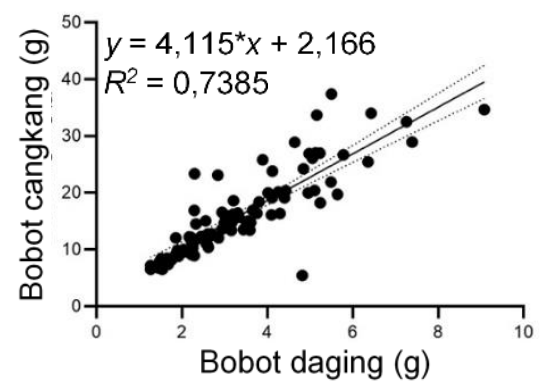

Tibang

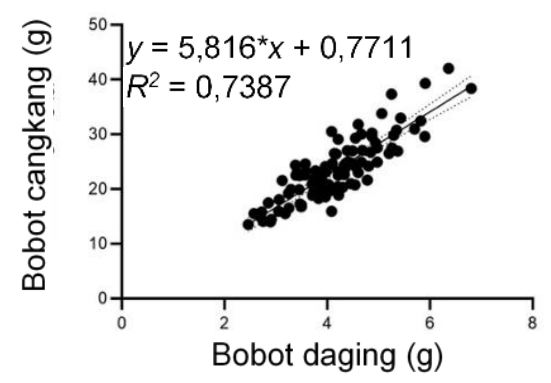

Deah Raya

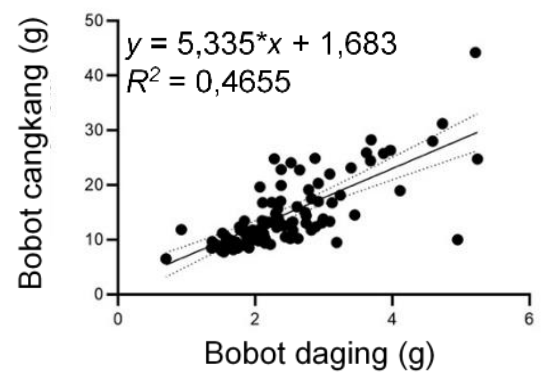

Gambar 5 Kerelasi antar bobot daging, bobot cangkang, dan bobot total kerang darah dari setiap stasiun penelitian 
pembentukan cangkang dan hubungannya dengan bobot daging kerang darah masih belum ditemukan.

\section{KESIMPULAN}

Kerang darah yang dikoleksi dari pesisir utara Banda Aceh memiliki pola pertumbuhan (alometrik negatif) dan nilai faktor kondisi yang identik. Kerang darah yang dikoleksi dari Deah Raya dan Alue Naga memiliki nilai rata-rata panjang cangkang dan bobot total yang lebih rendah dibandingkan dengan kerang darah yang dikoleksi dari Tibang. Namun demikian, kerang darah yang dikoleksi dari Alue Naga memiliki rasio bobot daging yang lebih tinggi dibanding yang dikoleksi dari kedua lokasi lainnya. Selain itu, nilai korelasi antara bobot daging dan bobot total kerang darah dari Deah Raya juga cenderung lebih rendah dibanding kerang darah dari daerah Alue Naga dan Tibang. Kondisi biometrik dapat dijadikan indikator untuk menilai kesehatan kerang darah. Perlu penelitian lanjutan untuk mengetahui ada tidaknya pencemaran di pesisir utara Banda Aceh serta kaitannya dengan pertumbuhan kerang darah.

\section{DAFTAR PUSTAKA}

Ali M, Salam A, Iqbal F. 2001. Effect of environmental variables on body composition parameters of Channa punctata. Journal of Research Science. 12(2): 200-206.

Barus BS, Aryawati R, Putri WAE, Nurjuliasti E, Diansyah G, Sitorus E. 2019. Hubungan N-total dan C-organik sedimen dengan makrozoobentos di perairan Pulau Payung, Banyuasin, Sumatera Selatan. Jurnal Kelautan Tropis. 22(2): 147-156. https://doi.org/10.14710/jkt.v22i2.3770

Bayne B, Moore M, Widdows J, Livingstone D, Salkeld P. 1979. Measurement of the responses of individuals to environmental stress and pollution: studies with bivalve molluscs. Philosophical Transactions of the Royal Society of London. Biological Sciences. 286(1015): 563-581. https:// doi.org/10.1098/rstb. 1979.0046

Broom M. 1982. Analysis of the growth of Anadara granosa (Bivalvia: Arcidae) in Natural, artificially seeded and experimental populations. Marine ecology progress series. Oldendorf. 9(1): 69-79. https://doi.org/10.3354/meps009069

Chi C-F, Hu F-Y, Wang B, Li T, Ding G-F. 2015. Antioxidant and anticancer peptides from the protein hydrolysate of blood clam (Tegillarca granosa) muscle. Journal of Functional Foods. 15: 301-313. https://doi.org/10.1016/j.jff.2015.03.045

Cibic T, Fazi S, Nasi F, Pin L, Alvisi F, Berto D, Viganò L, Zoppini A, Del Negro P. 2019. Natural and anthropogenic disturbances shape benthic phototrophic and heterotrophic microbial communities in the Po River Delta system. Estuarine, Coastal and Shelf Science. 222: 168-182. https://doi.org/10.1016/j.ecss.2019.04.0 09

Davenport J, Wong TM. 1986. Responses of the blood cockle Anadara granosa (L.) (Bivalvia: Arcidae) to salinity, hypoxia and aerial exposure. Aquaculture. 56(2): 151-162. https://doi.org/10.1016/0044-8486 (86) $90024-4$

De Robertis A, Williams K. 2008. Weight-length relationships in fisheries studies: the standard allometric model should be applied with caution. Transactions of the American Fisheries Society. 137(3): 707-719. https://doi.org/10.1577/T07-124.1

Dewi SE, Eddiwan E, Efawani E. 2019. Morphometric and growth patterns of the blood clam (Anadara granosa) from the Bagan Siapi-Api coastal area Rokan Hilir. Berkala Perikanan Terubuk. 46(3): 37-45. https://doi.org/10.31258/terubuk.46.3.37-45

Dody S, Mumpuni FS, Madi W. 2018. Hubungan panjang-berat, nisbah kelamin, dan indeks kematangan gonad kerang darah (Anadara granosa LINN. 1758) di perairan Muara Gembong-Bekasi. Jurnal MIna Sains. 4(2): 67-75. https://doi.org/10 .30997/jms.v4i2.1517

Froese R. 2006. Cube law, condition factor and weightlength relationships: history, meta-analysis and recommendations. Journal of Applied Ichthyology. 22(4): 241-253. https://doi.org/10.1111/j.1439-042 6.2006.00805.x

Gimin R, Mohan R, Thinh L, Griffiths A. 2004. The relationship of shell dimensions and shell volume to live weight and soft tissue weight in the mangrove clam, Polymesoda erosa (Solander, 1786) from northern Australia. NAGA, WorldFish Center Quarterly. 27(3-4): 32-35.

Guan X, Shi W, Zha S, Rong J, Su W, Liu G. 2018. Neurotoxic impact of acute $\mathrm{TiO} 2$ nanoparticle exposure on a benthic marine bivalve mollusk, Tegillarca granosa. Aquatic Toxicology. 200: 241-246. https://doi.org/10.1016/j.aquatox.2018.05 .011

Hashim NH, Mohamat-Yusuff F, Joni AA, Mohd Kusin F, Mohamed KN, Zulkeflee Z, Asha'ari ZH, Zahmir Zulkifli S. 2020. Determination of median lethal concentration (Ic50) and nitrite accumulation in the blood and tissue of blood cockle (Tegillarca granosa, Linnaeus 1758). Water. 12(8): 2197. https://doi.org/10.3390/w12082197

Imamsyah A, Arthana IW, Astarini IA. 2020. The influence of physicochemical environment on the distribution and abundance of mangrove gastropods in Ngurah Rai Forest Park Bali, 
Indonesia. Biodiversitas Journal of Biological Diversity. 21(7). https://doi.org/10.13057/biodiv/d21 0740

Jabang N, Marusin N, Izmiarti A, Asmara RD, Marzuki J. 2006. Kepadatan populasi dan pertumbuhan kerang darah Anadara antiquate L (Bivalvia: Arcidae) di Teluk Sungai Pisang, Kota Padang, Sumatera Barat. . Makara Sains. 10(2): 96-101.

Joni AAM, Yusuff FM, Mohamed KN, Kusin FM, Zulkifli SZ. 2019. Growth Performance of Blood Cockle (Tegillarca granosa) within Kongkong Laut Estuaries, Masai, Johor. Pertanika Journal of Science \& Technology. 27(4).

Kätterer T, Bolinder M, Berglund K, Kirchmann $\mathrm{H}$. 2012. Strategies for carbon sequestration in agricultural soils in northern Europe. Acta Agriculturae Scandinavica, Section A-Animal Science. 62(4): 181-198. https://doi.org/10.1080/0 9064702.2013.779316

Ketjulan R, Boer M, Imran Z, Siregar VP. 2019. Daya dukung lahan untuk pemukiman penduduk dan implikasinya terhadap kualitas perairan di pulaupulau kecil (kasus pulau-pulau kecil Selat Tiworo Kabupaten Muna Barat). Jurnal IImu dan Teknologi Kelautan Tropis. 11(3): 569-582. https://doi.org/10 .29244/jitkt.v11i3.25731

Khade S, Mane U. 2012. Diversity of Bivalve and Gastropod, Molluscs of some localities from Raigad district, Maharashtra, west coast of India. Recent Research in Science and Technology. 4(10).

Khalil M, Ezraneti R, Rusydi R, Yasin Z, Tan SH. 2021. Biometric Relationship of Tegillarca granosa (Bivalvia: Arcidae) from the Northern Region of the Strait of Malacca. Ocean Science Journal. 1-11. https://doi.org/10.1007/s12601-021-00019-x

King M. 1995. Fisheries biology, assessment and management. India (IN): Blacwell Publising.

Komala R, Yulianda D, Lumbanbatu IS, Setyobudiandi I. 2011. Indeks kondisi kerang darah (Anadara granosa) sebagai indikator kualitas lingkungan di Teluk Lada perairan Selat Sunda. Bioma. Jurnal Jurusan Biologi, FMIPA, Universitas Negeri Jakarta. 9(2): 8-12.

Lai ZW, Teoh HW, Lee CW, Lee SL, Saito H, Chong VC. 2020. Macrobenthic community associated with semi-cultured blood cockles (Tegillarca granosa) in tropical mudflats. Continental Shelf Research. 195: 104061. https://doi.org/10.1016/j.csr.2020.104061

Lam NN, Hai DN. 1998. Gut content of blood cockle, Anadara granosa (L.), with emphasis on diatoms, Tra Vinh, South Vietnam. Paper presented at the Proceedings of the Eighth Workshop of the Tropical Marine Mollusc Programme TMMP. Hylleberg, J.(ed.).
Masitah I, Chong V. 2002. Population and feeding ecology of Parapenaeopsis scuiptilis (Heller, 1862) in Klang Strait, Peninsular Malaysia. Malaysian Journal of Science, 21(1\&2): 60-68.

Mohamat-Yusuff F, Zulkarnain Z, Anuar NZA, Joni AAM, Kusin FM, Mohamed KN, Zulkeflee Z, Asha'ari ZH, Zulkifli SZ, Arshad A. 2020. Impact of diuron contamination on blood cockles (Tegillarca granosa Linnaeus, 1758). Marine Pollution Bulletin. 161: 111698. https://doi.org/10.1016/j.marpolbul.20 20.111698

Nakamura Y, Shinotsuka Y. 2007. Suspension feeding and growth of ark shell Anadara granosa: comparison with ubiquitous species Scapharca subcrenata. Fisheries Science, 73(4): 889-896. https://doi.org/10.1111/j.1444-2906.2007.01410.x

Nur FM, Batubara AS, Eriani K, Tang U, Muhammadar AA, Siti-Azizah MN, Wilkes M, Fadli N, Rizal S, Muchlisin ZA. 2020. Effect of water temperature on the physiological responses in Betta rubra, Perugia 1893 (Pisces: Osphronemidae). International Aquatic Research. 12(3): 209-218.

Nurdin J, Marusin N, Asmara A, Deswandi R, Marzuki J. 2010. Kepadatan Populasi dan Pertumbuhan Kerang Darah Anadara antiquata L.(bivalvia: Arcidae) di Teluk Sungai Pisang, Kota Padang, Sumatera Barat. Makara Journal of Science. 10(2): 96-101. https://doi.org/10.7454/mss.v10i2.201

Pathansali D, Soong MK. 1958. Some aspects of cockle (Anadara granosa L.) culture in Malaya. Proceedings of the Indo-Pacific Fisheries Council. 8(2): 26-31.

Prasojo SA, Irwani I, Suryono CA. 2012. Distribusi dan kelas ukuran panjang kerang darah (Anadara granosa) di perairan pesisir Kecamatan Genuk, Kota Semarang. Journal of Marine research. 1(1): 137-145.

Ray NE, O'Meara T, Wiliamson T, Izursa J-L, Kangas PC. 2018. Consideration of carbon dioxide release during shell production in LCA of bivalves. The International Journal of Life Cycle Assessment. 23(5): 1042-1048. https://doi.org/10.1007/s11367017-1394-8

Restrepo JD, Escobar HA. 2018. Sediment load trends in the Magdalena River basin (1980-2010): Anthropogenic and climate-induced causes. Geomorphology. 302: 76-91. https://doi.org/10.101 6/j.geomorph.2016.12.013

Setiawan I, Miswar E, Zulfahmi I, Yuni S. 2019. Distribution of sediment grain size in Kajhu coastal area, Aceh Besar District, Indonesia. Paper presented at the IOP Conference Series: Earth and Environmental Science. https://doi.org/10.1088/175 $5-1315 / 348 / 1 / 012107$ 
Shi W, Han Y, Guo C, Su W, Zhao X, Zha S, Wang Y, Liu G. 2019. Ocean acidification increases the accumulation of titanium dioxide nanoparticles (nTiO 2) in edible bivalve mollusks and poses a potential threat to seafood safety. Scientific reports. 9(1): 1-10. https://doi.org/10.1038/s41598-019-400 47-1

Shin YK, Moon T-S. 2005. Temperature tolerance and physiological changes of blood cockle, Tegillarca granosa. Korean Journal of Fisheries and Aquatic Sciences. 38(4): 251-256. https://doi.org/10.5657/k fas.2005.38.4.251

Stevenson R, Woods Jr WA. 2006. Condition indices for conservation: new uses for evolving tools. Integrative and Comparative Biology. 46(6): 1169-1190. https://doi.org/10.1093/icb/icl052

Sturges HA. 1926. The choice of a class interval. Journal of the american statistical association. 21(153): 65-66. https://doi.org/10.1080/01621459 .1926 .10502161

Sukina B, Ahmad A, Rasmaniar R. 2020. Kandungan gizi kerang bakau (Telescopium telescopium), kerang kalandue (Polymesoda erosa), Dan Kerang Darah (Anadara granosa L.) dari Kota Kendari. Jurnal Sains dan Teknologi Pangan. 5(2).

Suryono CA, Suprijanto J. 2014. Variasi ukuran kerang darah (Anadara granosa) di perairan pesisir Kecamatan Genuk Kota Semarang. Journal of Marine Research. 3(2): 122-131.

Taufiq N, Hartati R. 2000. Relationships between organic matter sediment and abundance, condition index, and growth of cockle Anadara granosa L. In three Indonesian estuaries. Paper presented at the Proceedings of the Phuket marine biological center spesial publication.

Triatmaja RA, Pursetyo KT, Triastuti J. 2019. The density of blood cockle (Tegillarca granosa) population in the river estuary of industrial area. Aquaculture, Aquarium, Conservation \& Legislation. 12(4): 1025-1030.

Van der Wal D, Herman P, Forster R, Ysebaert T, Rossi F, Knaeps E, Plancke Y, Ides S. 2008. Distribution and dynamics of intertidal macrobenthos predicted from remote sensing: response to microphytobenthos and environment. Marine Ecology Progress Series. 367: 57-72. https://doi .org/10.3354/meps07535

You Z, Xu S, Bian P, Chen J. 2001. The effects of sea water temperature and salinity on the growth and survival of Tegillarca granosa larvae and juveniles. Acta Oceanologica Sinica. 23(6): 108-113.

Yurimoto T, Tanaka K, Nasu H, Matsuoka K. 2008. Influence of resuspended sediments and their surface accumulation on a pen shell Atrina pectinata in Ariake Bay, West Japan. Aquaculture science. 56(3): 335-342.

Yurimoto T, Kassim FM, Fuseya R, Man A. 2014. Mass mortality event of the blood cockle, Anadara granosa, in aquaculture ground along Selangor Coast, Peninsular Malaysia. International Aquatic Research, 6(4): 177-186. https://doi.org/10.1007 /s40071-014-0077-3

Yurimoto T, Kassim FM, Fuseya R, Matsuoka K, Man A. 2021. Food availability estimation of the blood cockle, Anadara granosa (Linnaeus, 1758), from the aquaculture grounds of the Selangor Coast, Malaysia. International Journal of Aquatic Biology. 9(2): 88-96.

Zhou Y, Wang L, Zhou Y, Mao X-Z. 2020. Eutrophication control strategies for highly anthropogenic influenced coastal waters. Science of the Total Environment. 705: 135760. https://doi. org/10.1016/j.scitotenv.2019.135760

Zulfahmi I, Rahmi Y, Sardi A, Mahyana M, Akmal Y, Rumondang R, Paujiah E. 2021a. Biometric condition of Seurukan Fish (Osteochillus Vittatus Valenciennes 1842) exposed to mercury in Krueng Sabee River Aceh Jaya Indonesia. Elkawnie: Journal of Islamic Science and Technology. 7(1): 67-83. https://doi.org/10.22373/ekw.v7i1.8258

Zulfahmi I, Yuliandhani D, Sardi A, Kautsari N, Akmal Y. 2021b. Variasi morfometrik, hubungan panjang bobot dan faktor kondisi ikan famili Holocentridae yang didaratkan di Pelabuhan Perikanan Samudra (PPS) Lampulo, Banda Aceh. Jurnal Kelautan Tropis. 24(1): 81-92. https://doi.org/10.14710/jkt.v2 $4 \mathrm{i} 1.9767$ 